\title{
Migrant Workers Empowerment through Productive Migrant Village Programs in Banyumas, Indonesia
}

\author{
Muslihudin 1,*, (D), Tyas Retno Wulan 1, (D), Tri Sugiarto 1, (D), \\ Sotyania Wardhianna ${ }^{2,}$ (D), and Sri Wijayanti ${ }^{3}$,
}

${ }^{1}$ Department of Sociology, Faculty of Social and Political Sciences,

Universitas Jenderal Soedirman, 53122, Purwokerto, Central Java Province, Indonesia

2 Department of Community Health, Faculty of Health Sciences,

Universitas Jenderal Soedirman, 53122, Purwokerto, Central Java Province, Indonesia

${ }^{3}$ Department of International Relations, Faculty of Social and Political Sciences,

Universitas Jenderal Soedirman, 53122, Purwokerto, Central Java Province, Indonesia

* Corresponding Author: muslihudin1963@yahoo.com

\section{ARTICLE INFO}

\section{Publication Info:}

Research Article

How to cite:

Muslihudin, M., Wulan, T. R., Sugiarto, T., Wardhianna, S., E Wijayanti, S. (2021). Migrant Workers Empowerment through Productive Migrant Village

Programs in Banyumas,

Indonesia. Society, 9(1), 319-330.

DOI: $10.33019 /$ society.v9i1.261

Copyright () 2021. Owned by Author(s), published by Society

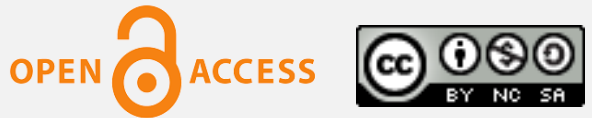

This is an open-access article.

License: Attribution-

NonCommercial-ShareAlike (CC BY-NC-SA)

\section{ABSTRACT}

This study explains empowering Indonesian Migrant Workers (IMW) through Productive Migrant Village Programs (PMVP) in the Banyumas Regency. PMVP is a program of the Ministry of Manpower of the Republic of Indonesia held since 2016. The program aims are to empower, improve services and protection for IMWs starting from the village. The paradigm of the study is a constructivist paradigm by using a critical model. The research method used is a qualitative method with a phenomenological approach, which explores data to get the meaning of the basic and essential things of the empirical phenomena experienced by the research subject. The results of the research are 1). In providing information about the process of migrant workers faced with challenges from recruitment agencies/recruitment companies (Private Indonesian Migrant Worker Placement Agency). 2). In the stage of the production process, there are obstacles that the equipment provided by the Ministry cannot use. 3). The care of children of migrant workers is still individual only to their families. The community even still stigmatizes them as children who deserve problems since their parents abandoned them. 4). Late initiation of the migrant workers' cooperatives. Procedures for establishing migrant workers cooperatives, mentoring, and guidance specifically related to migrant workers are needed. 


\section{Migrant Workers Empowerment through Productive Migrant Village Programs in Banyumas, Indonesia}

Received: November 11, 2020;

Accepted: March 4, 2021;

Published: June 30, 2021;
Keywords: Empowerment; Migrant Workers; Productive Migrant Village

\section{Introduction}

Household economic empowerment is an entry point for advancing community welfare (Lestari et al., 2019). The Productive Migrant Village Program (PMVP) was initiated by the Ministry of Manpower of the Republic of Indonesia in 2016 to empower, improve services, and protect Indonesian Migrant Workers from the village. Productive Migrant Village develops four main pillars: 1) provides information on safe town migration services; 2) Improve the productive effort of IMWs and their families; 3) Active parenting community for children of IMWs lives by their parents to work abroad, and 4) Strengthening long-term productive enterprises through cooperatives.

The Productive Migrant Village Program is expected to answer the problems IMWs and their families face, given the high number of IMWs working abroad. In 2015, based on data from the Indonesian Migrant Workers Protection Agency (Badan Pelindungan Pekerja Migran Indonesia or BP2MI), formerly known as the National Agency for the Placement and Protection of Indonesian Migrant Workers (Badan Nasional Penempatan dan Perlindungan Tenaga Kerja Indonesia or BNP2TKI), there were 6,5 Million of Indonesian Migrant Workers (IMWs), which works in 142 countries around the world. The high number of IMWs who work abroad is not balanced by adequate protection for IMW. In 2013, based on the BP2MI Crisis Center data, at least 13 thousand cases affected IMWs in various countries, 300 of which were threatened with death sentences.

In addition, the case in the destination country, an investigation based on Wulan et al. (2016), Muslihudin et al. (2019; 2020) fundamental problems experienced by the IMWs includes the following three main issues, namely: abundantly fundamental rights of children who are left behind (Children "Left Behind") or CLB. IMWs family insecurity has implications for the divorce and weak ability management of economic remittances the results of working abroad. Productive Migrant Village focused on four pillars: the secure migration information, productive business for IMWs and family, parenting community for IMWs children, and establishing a cooperative for the long term is conceptually beneficial to resolve these problems. During this time, government programs related to IMWs protection are not comprehensive and integrative like this, but more in the form of spatial and unsustainable programs, more of a case handling, not prevention.

In 2016, the Productive Migrant Village was implemented in two pilot areas in Indonesia, namely Kenanga Village, Sindang Sub-district, Indramayu Regency, West Jawa Province, and Kuripan Village, Watumalang Sub-district, Wonosobo Regency, Central Java Province. In 2017, 120 Productive Migrant Village was formed, covering 100 villages in 50 regency/municipalities from the hometown of Indonesian Migrant Workers and 20 villages in 10 regency/municipalities in East Nusa Tenggara Province. It including two villages in Banyumas Regency, namely Losari Village, Rawalo Sub-district, and Cihonje Village, Gumelar Sub-district.

The village is the smallest representation of the state that deals directly with citizens. The city is also an autonomous collective that mobilizes the community's social, economic, and political dynamics. Concerning about IMWs protection, the village should be the entry point of protection for citizens going abroad. Unfortunately, research results have shown that villages that should be the front line for migrating villagers have not actively provided services such as

Copyright (C) 2021. Owned by Author(s), published by Society. This is an open-access article under the CC-BY-NC-SA license. 
the absence of a valid migrant workers database from the village and only giving permission letters from prospective husbands or wives or parents migrant workers. If the sponsor/broker asks for a letter from the village, even village officials or even the village head concurrently act as a broker (Hidayah \& Susilo, 2016; Wulan et al., 2016).

Another previous research is Rosiyanti \& Gustaman (2020) on empowering former women migrant workers in Purworejo Village, Kendal Regency. The results of research concluded that empowerment of former women migrants workers in the village was only at the level of participation. This means that it has not yet produced an empowered community as expected. This means that it is still in an early stage that needs to be accompanied and encouraged continuously. The descriptive program includes four activities, namely cooking, making batik cloth, sewing, and knitting.

Likewise, Nuraeini (2018) on her research on the productive migrant village program, concluded that most of the 111 villages sampled had abundant natural resource potential to develop agro-industry-based MSMEs. For the success of the productive migrant village program, a strategy is needed to integrate programs across Ministries/Agencies following national priority programs. Optimizing the existence of local partners who are willing to work together to make the productive migrant village program a success is the key to developing agro-industry-based MSMEs in Indonesian Migrant Workers.

Other researchers who have reviewed the implementation of the productive migrant village program are Mindarti \& Nabil (2019) and Bastaman et al. (2020). They conclude that the empowerment of productive migrants has not shown the results expected by the government, especially the Ministry of Manpower. The form of a not yet successful program is that the results are not optimal. The ineffective implementation of the program includes timeliness, human resources, work mechanisms, cooperation and communication, correct distribution of funds, no deviation, monitoring, and evaluation.

This study aimed to explain the successes and obstacles in empowerment through productive migrant village programs, especially in Banyumas Regency. The identification of successes and obstacles will help realize programs that will be carried out in other villages. Many types of research on empowerment have been carried out, but the empowerment of productive migrant village programs has never existed, especially in Banyumas Regency. That's why research is important to carry out.

\section{Research Methodology}

The primary method used in the study is a method with a constructivist paradigm, but this research also uses a critical model. Salim (2013) explains that the constructive paradigm reveals the details of a particular community culture by understanding its cultural setting naturally with the point of view of the subject under study, so this study uses a constructivist paradigm. The methodological consequence of this paradigm choice is to use a qualitative methodology. The type of approach is phenomenological, namely exploring data to get the meaning of the basic and essential things of empirical phenomena and the experiences experienced by the research subjects.

\subsection{Research Subject}

The main targets of this research are village government officials, labor officials, and village assistants for productive migrant programs. Supporting informants are former Indonesian migrant workers who are active in the productive migrant village program. Determining

Copyright (C) 2021. Owned by Author(s), published by Society. This is an open-access article under the CC-BY-NC-SA license. https://doi.org/10.33019/society.v9i1.261 
research subjects is purposive, considering those who know and are involved in productive migrant village programs.

The number of informants used as research subjects was as follows: 1) two village heads; 2) two assistant officers of productive migrant village program in Cihonje Village, and two people in Losari Village so that there were four people; 3) there are 20 productive working group members of the migrant village in Cihonje Village and 20 people in Losari Village, totally 40 people; 4) two employees of Manpower Office of Banyumas Regency. Thus the total number of informants was 48 people.

\subsection{Data Collection Techniques}

Data collection techniques used in this study are: in-depth interviews, namely in the form of dialogue, both individually and collectively with the village government, and making observations involved (participant observation) to obtain information about the issues more thoroughly and deeply. Other data collection techniques are FGD (Focus Group Discussion) or limited focus group discussions to get comprehensive information from informants. Besides, a collaborative learning process is also conducted between researchers and informants and efforts to disseminate interim research results with informants in training. At the same time, secondary data from the Ministry of Manpower and various other secondary data provided jug with a used empirically.

\subsection{Location and Time of Research}

The site of this study was in the Losari Village, Rawalo Sub-district, and Cihonje Village, Gumelar Sub-district, Banyumas Regency. The two locations are the subject of research because the two villages are the pilot productive migrant village program in the Banyumas Regency. The two villages were used as a pilot for the productive migrant village program because of the highest IMWs in the Banyumas Regency. The research was done in two stages; the first phase was in 2018, from February 2018 until December. The second phase was carried out in 2019.

\section{Results and Discussions}

\subsection{Description of Indonesian Migrant Workers}

Banyumas Regency is one of the largest that sending for Indonesian Migrant Workers in Central Java Province. Based on BP2MI data in 2016, Banyumas was ranked 16th out of the 25 most IMWs sending regencies in Indonesia and the fourth place in Central Java after Cilacap, Kendal, and Brebes. The large number of IMWs means that the foreign exchange earned is also significant. Prihatinah et al. (2012) state that migrant workers be the most significant contributor of foreign exchange after oil and gas. Cilacap Regency, as the largest sending regencis of IMWs in Central Java, received an international trade of Rp372 billion in 2009. This amount is three times that of the original regional income, only Rp105 billion.

The data of migrant workers in Banyumas Regency departing abroad is quite large. An illustration of the IMWs shipping data from the Banyumas Regency in 2017 can be seen in Table 1 that shows the delivery of IMWs in the period one year reaches 2,657 people. Female workers are $2,274(85,59)$ percent, while male workers are only 383 people or 14.41 percent. The size of the female migrant worker's portion of men makes the families' problems more complex than the abandoned male workers. There are at least parenting problems for IMWs children, especially for toddlers. For this reason, the pillars of the third productive migrant village program on community parenting are essential. 
Migrant Workers Empowerment through Productive Migrant Village Programs in Banyumas, Indonesia

Table 1. Placement of Banyumas' Indonesian Migrant Workers in 2017

\begin{tabular}{|c|c|c|c|c|c|c|c|c|}
\hline \multirow{2}{*}{ No. } & \multirow{2}{*}{$\begin{array}{c}\text { COUNTRY } \\
\text { OF } \\
\text { PLACEMENT }\end{array}$} & \multicolumn{3}{|c|}{ INFORMAL } & \multicolumn{3}{|c|}{ FORMAL } & \multirow{2}{*}{ TOTAL } \\
\hline & & $\mathrm{F}$ & M & $\sum$ & $\mathrm{F}$ & M & $\sum$ & \\
\hline 1 & $\begin{array}{l}\text { Brunei } \\
\text { Darussalam }\end{array}$ & 5 & 0 & 5 & 1 & 2 & 3 & 8 \\
\hline 2 & Hong Kong & 516 & 0 & 516 & 0 & 0 & 0 & 516 \\
\hline 3 & Japan & 0 & 0 & 0 & 3 & 3 & 6 & 6 \\
\hline 4 & $\begin{array}{l}\text { Korea } \\
\text { South }\end{array}$ & 0 & 0 & 0 & 38 & 215 & 253 & 253 \\
\hline 5 & Malaysia & 242 & 1 & 243 & 319 & 74 & 393 & 636 \\
\hline 6 & Qatar & 0 & 0 & 0 & 0 & 1 & 1 & 1 \\
\hline 7 & Singapore & 435 & 0 & 435 & 0 & 0 & 0 & 435 \\
\hline 8 & Taiwan & 702 & 2 & 704 & 13 & 78 & 91 & 796 \\
\hline \multirow[t]{2}{*}{9} & $\begin{array}{l}\text { United Arab } \\
\text { Emirates }\end{array}$ & 0 & 0 & 0 & 0 & 7 & 7 & 7 \\
\hline & Total & 1900 & 3 & 1903 & 374 & 380 & 754 & 2657 \\
\hline
\end{tabular}

Source: Ministry of Manpower (2017)

Table 1 shows that the departure of IMWs through informal channels or privately managed much more than through a formal channel or managed by the government. The comparison is 903 people or 71, 62 percent compared to 754 people or 28.38 percent. According to Ratnaningsih (2017), it is an old pattern that is no longer relevant to the mandate of Law Number 18 of 2017 on the Protection of Indonesian Migrant Workers (Republik Indonesia, 2017). The government should be more dominant in managing IMWs than the private sector.

Table 2 informs that IMWs from Banyumas Regency are categorized as very low educated, with an elementary school education of 921 or 34.66 percent, the junior high school also 921 or 34.66 percent. In comparison, those with high education are only 20 people or 0.75 percent. The low level of education, however, reflects the low quality of human resources. Latifah et al. (2016) stated that one of the obstacles to empowering former Indonesian workers was the low quality of support.

Table 2. Education Level of Banyumas' IMWs in 2017

\begin{tabular}{ccccccccc}
\hline & \multicolumn{1}{c}{ LEVEL OF } & \multicolumn{3}{c}{ INFORMAL } & \multicolumn{3}{c}{ FORMAL } & \multirow{2}{*}{ TOTAL } \\
\hline No. & EDUCATION & F & M & JML & F & M & JML & \\
\hline 1 & $\begin{array}{l}\text { Elementary } \\
\text { School }\end{array}$ & 877 & 1 & 878 & 9 & 34 & 43 & 921 \\
2 & $\begin{array}{l}\text { Junior High } \\
\text { School }\end{array}$ & 644 & 0 & 644 & 179 & 98 & 277 & 921
\end{tabular}

Copyright ( $(2021$. Owned by Author(s), published by Society. This is an open-access article under the CC-BY-NC-SA license. https://doi.org/10.33019/society.v9i1.261 


\begin{tabular}{llccccccc}
\hline \multirow{2}{*}{ No. } & LEVEL OF & \multicolumn{3}{c}{ INFORMAL } & \multicolumn{3}{c}{ FORMAL } & \multirow{2}{*}{ TOTAL } \\
& \multicolumn{1}{c}{ EDUCATION } & F & M & JML & F & M & JML & \\
\hline \multirow{2}{*}{3} & Senior High & 273 & 2 & 275 & 109 & 217 & 326 & 601 \\
& School & & & & & & \\
4 & Vocational School & 104 & 0 & 104 & 66 & 24 & 90 & 194 \\
5 & Diploma & 2 & 0 & 2 & 9 & 5 & 14 & 16 \\
6 & Bachelor & 0 & 0 & 0 & 2 & 2 & 4 & 4 \\
\hline & \multicolumn{1}{c}{ TOTAL } & 1900 & 3 & 1903 & 374 & 380 & 754 & 2657 \\
\hline
\end{tabular}

Source: Ministry of Manpower (2017)

IMWs' low level of education is challenging to support the government's desire that the proportion of Indonesian workers who work as domestic servants does not increase. Bareta \& Ispriyarso (2018) stated that the government's zero-growth desire or target of household help. With the low level of education of IMWs, it doesn't seem easy to fulfill domestic workers' wishes, and it is not an option that can accept them to work abroad.

Atmaja (2014) stated that one of the root causes of migrant workers' is an imbalance between employment and human resources available. From the problem of unemployment, we can see that educated unemployment still has a large enough number. The unemployment with the level of education up to high school will think twice about fighting for jobs. These problems are twice with the problem of poverty that plagues Indonesian society. It has become a significant driving factor in the presence of Indonesian Workers abroad. Employment and income levels are high enough to be the main attraction of these migrant workers.

\subsection{Productive Migrant Village Constraints}

The empowering of migrant workers that arise in implementing the Productive Migrant Village Program (PMVP) in the Banyumas Regency is seen in each program.

\subsubsection{Providing Migration Information and Services}

The government is obliged to facilitate orderly, safe, organized, and responsible migration and population mobility, including implementing well-planned and well-managed migration policies (Hidayati, 2019). Through the center of employment information and migration services, villagers who want to work at home and abroad get labor market information and work guidance/counseling (i.e., information through training). Information on how to become migrant workers following the procedure, and document-making services for prospective labor migrants as requirements for producing passports (such as identity cards, family certificates, certificates, and other documents) carried out at the village hall through an active role from the village government. The service center also works to help resolve the problems of migrant workers by providing a reference to the competent authorities (e.g., Police, Manpower Office, Indonesian Migrant Worker Placement and Protection Service Center (BP3TKI), or NGOs).

This excellent program is not necessarily easily realized in the field. Productive Migrant Village in Losari Village and Cihonje Villagewhich has been running nearly two years, establishing the database of IMWs both those who are active abroad and those who have returned are continue. It means that the primary data for identification alone is not complete, let 
alone to help at a more complicated level. This condition occurs due to the lack of quantity and quality of productive migrant villages, especially concerning research or data collection, supported by a lack of secondary data in the Productive Migrant Village.

Constraints that are no less important are external. These external constraints are institutions like Private Indonesian Migrant Worker Placement Agency, once known as an Indonesian Employment Service Company. This first productive migrant village program led to the administration of IMWs departures by the government faced the interests of private institutions. In providing information about the process of migrant workers faced with challenges from individual manpower suppliers.

Concerning about IMWs protection, the village should be the entry point of protection for citizens going abroad. Unfortunately, research results have shown that villages that should be the front line for migrating villagers have not actively provided services such as the absence of a valid migrant workers database from the village and only giving permission letters from prospective husbands or wives or parents migrant workers. If the sponsor/broker asks for a letter from the village, even village officials or even the village head concurrently act as a broker (Hidayah \& Susilo, 2016; Wulan et al., 2016). This condition was confirmed by Kolopaking (2016) in her research in Tugu Selatan Cisarua village, the destination village for migrants from the Middle East. The village government is only oriented to providing services to migrants without planning to accommodate the interests of the villagers.

\subsubsection{Developing Productive Businesses}

They are helping Indonesian migrant workers, and their families develop the skills and willingness to grow productive businesses through training, mentoring, and assistance in productive business facilities to marketing.

In realizing this second program of the productive migrant village, both the central government, local government, and village government seem less careful reading opportunities, needs, and constraints experienced independent business group of the productive migrant village in two pilot areas. It can be seen from the assistance of production equipment in the former IMWs group that it cannot function as it should so that the set of tools is only stored in productive migrant village learning offices/homes. Such cases often occur in the implementation of government programs that are top-down planning and project-oriented only.

The next obstacle was the limited marketing of business results caused by the lack of network marketing. Production results are also not feasible to compete with products that are already running and have market control. For example, the packaging is simple, there is no information on the expiry date, permit are also not available, and material compositions. Program constraint in both productive migrant villages seems to require a touch of entrepreneurial spirit. Entrepreneurship training or transmission to former IMWs and facilitators must be strengthened to become a leader in the productive migrant village. The research results by Astuti et al. (2019) and Cipta (2019) conclude that the entrepreneurial spirit needs to be instilled in the community even from a young age and made into local culture.

In line with the results of this study, Nuraeni (2018) concludes that the Productive Migrant Village Program, especially pillar 2 (productive business development) and component 4 (Productive Migrant Village Program Cooperative development), are very strategic to support local communities to develop agro-industry-based MSME. It was based on the dominant survey on agriculture/plantation and fisheries and agro-industry initiated by many local communities,

Copyright (C) 2021. Owned by Author(s), published by Society. This is an open-access article under the CC-BY-NC-SA license.

https://doi.org/10.33019/society.v9i1.261

325 
namely food/beverage industries from various superior commodities from agricultural, farm, fisheries, and livestock products.

\subsubsection{Facilitating the Establishment of Community Care and Child Development (Community Parenting)}

This program is based on the fact that most Indonesian migrant workers abroad have children left in their home villages. Reni et al. (2016) showed that marital status was negative and significant, meaning that the probability of married IMWs deciding to migrate was higher than the likelihood of unmarried respondents. So it appears that the respondent's marital status influences the opportunity to decide to migrate. For someone who is bound by marriage, then the burden of life borne will increase. Likewise, the family dependency is marked negative and significant, meaning that the probability of respondents who have the same responsibility of 3 people or $\geq$ three lives per family in deciding to migrate is smaller than the likelihood of respondents having a burden of $\leq 3$ people per family in their origin area. So it appears that the family burden affects the opportunity to migrate, according to the number of dependents on the respondent's family in the area of origin between 1 and 6 people.

Likewise, Prasetyo (2017), who examines the psychological condition of children in migrant families, concludes that the family as the smallest social unit in the community still needs to consider the impact of the phenomenon of migration. Commitment and excellent communication between husband and wife are essential in caring for children in migrant families. Plus, if you see the problems that arise from the presence of migrating mothers, it turns out there is more than a positive impact. Thus, decision-making in migrating still has to pay attention to the child's psychological condition as a top priority in a family.

Based on that, perhaps the program encourages the emergence of helping communities in forming communities whose job is to guide families of IMWs in educating, caring for, and guiding children correctly and adequately. The IMWs children are cared for together by the community through this activity in a teaching and learning center called "learning house," a productive migrant village. Parents and spouses who stay at home were given training on raising, caring for, educating, and guiding the children correctly and adequately to continue going to school until they graduate and develop their creativity.

In implementing the third program of the productive migrant village, the obstacles still exist are the care of migrant workers' children so far, and they are still individual only to families. The community even stigmatized that they deserved to be troubled as a child of IMWs because their parents left them behind. The town has not been called responsible for replacing the role of parents who become IMWs. Social solidarity has not yet been established, especially concerning children left by their mother or father to become IMW. What's more, if the husband/wife left by his partner to become IMWs is looking for a partner again. This kind of case makes the community or neighbor more indifferent and strengthens the stigma above.

Lailiyah (2018) concludes from her research that, in general, the obstacles that arise in child care are the figure of a mother who has difficulty in acting as a father and the process of self-adjustment from caregivers and children as well as things that affect the care carried out by the caregivers are; 1 . Children cared for by their biological mothers when their father works as migrant workers prefer authoritative care; 2 . The child cared for by his aunt when his biological mother works as a migrant worker prefers parenting by permissive indulgence; 3 . When both of their parents work as migrant workers, children cared for by distant relatives have a 
combination of care done authoritatively by their relatives and indifference permissive by their biological parents.

Program implementation of the guidance that runs is still limited to providing courses related to student subjects, for example, English courses, mathematics, re-citation. Ideally, the program should be integrated into handling the children of IMWs, but it isn't easy to realize.

\subsubsection{Facilitating the Establishment and Development of Cooperatives}

Establish and develop cooperatives that aim to strengthen the long-term and sustainable, productive efforts of the community. In realizing the fourth program, achieve cooperative organizations of their formation. There is no indication of the formation of cooperatives. However, a solid membership of the IMWs group is a solid capital for becoming cooperative. It's just that no booster and carrier towards the real cooperative. The former IMWs also do not feel that cooperation is an urgent need. At the same time, the cooperative is one of the social capital important for the progress of a society. With internal and external cooperation that is inclusive by building more networks with external potentials attached to it, it is easier for people to get access (Laura et al. 2018).

The unfavorable conditions of cooperatives arise and develop perhaps because of the contamination of the meaning of organizations, as concluded by Rochmadi (2011) that various developing problems regarding the existence of organizations, especially savings and loan cooperatives, are related to perceived cultural values and principles. As the principle factor of the nation's economic, it is no longer a cooperative as a mass organization of people and not a cooperative aimed at the welfare of its members. The phenomenon is that there are still many "black" cooperatives currently operating in Malang Regency, East Java Province, disturbing the community. Economic globalization has an adverse impact on the development of the world of cooperatives in Indonesia. There has been a shift in principles, principles, and objectives of shifting organizations seen from year to year experiencing an increase in changes, in 2009 amounting to $34.24 \%$; In 2010 it was 43.83 , and in 2011 it was $44.74 \%$.

If the cooperative formation program must be successful, it requires education about cooperatives, procedures for establishing organizations, conditions, prospects, benefits, and so on. The conditioning of former IMWs on the importance of cooperation for them needs to be done. Therefore, a specific book of appropriate technology related to migrant workers and intense training and mentoring from experts cooperatives is necessary.

\section{Conclusion}

Community empowerment in productive migrant village programs in Banyumas Regency conceptually until the programs launched are good enough. In the sense that the productive business program is based on the potential in the respective village environment. The main program launched by the central government, which consists of 4 pillars, namely: creating a database and providing information on migrant workers, productive businesses, caring for children, and forming cooperatives, have all been running. The productive business program gets the most response from the community, even though the program's implementation faces many obstacles.

These constraints relate to the conditions of the productive migrant village working group itself and problems related to the government. The condition of the working group is the lack of knowledge, entrepreneurship, and skills that are still lacking. The problem related to the 
government is that there is equipment assistance for productive businesses that the working group does not use at all because it does not match the required needs.

Suggestions that can be offered from the above conclusions are a need for continuous monitoring of the labor office and training for members of the administration related to skills in their productive business. In addition, the provision of equipment assistance to support productive businesses from the government must be based on the real needs of each village so that it will be useful and not stalled.

\section{Acknowledgment}

Thank you to the Institute for Research and Community Service of Universitas Jenderal Soedirman for funding this research, with Decree No. 62/UN23.6/KP.02.01/2019 and Agreement/Contract Number P/289/UN23/14/PN/2019. Thank you also to the Head of Cihonje Village, Gumelar Sub-district, the Head of Losari Village, Rawalo Sub-district, Banyumas Regency, and the Banyumas Regency Manpower and Transmigration Office. We would also like to thank the assisting officers and members of the productive migrant village program in the two villages, Cihonje Village and Losari Village, who provided information in this research.

\section{Declaration of Conflicting Interests}

The authors have declared no potential conflicts of interest concerning the study, authorship, and/or publication of this article,

\section{References}

Astuti, R. P., Bahtera, N. I., \& Atmaja, E. J. J. (2019). Entrepreneurial Characteristics and Behaviors of Muntok White Pepper Farmers. Society, 7(2), 101-115. https://doi.org/10.33019/society.v7i2.116

Atmaja, H. T. (2014). Keberadaan Keluarga TKW Jawa Timur Berbasis Arena Produksi Kultural. Forum Ilmu Sosial, 41(1), 1-14. https://journal.unnes.ac.id/nju/index.php/FIS/article/view/5375/4300

Bareta, R. D., \& Ispriyarso, B. (2018). Politik Hukum Perlindungan Tenaga Kerja Indonesia Fase Purna Bekerja. Kanun Jurnal Ilmu Hukum, 20(1), 163-182. https:// doi.org/10.24815/kanun.v20i1.9828

Bastaman, K., Nawawi, A., \& Taharudin, T. (2020). Efektivitas Program Desa Migran Produktif (DESMIGRATIF) Pada Dinas Tenaga Kerja dan Transmigrasi Kabupaten Subang. The World of Public Administration Journal, 2(2), 169-191. https://doi.org/10.37950/wpaj.v2i2.928

Cipta, H. (2019). Determinant Factors of Entrepreneurial Spirits among the Minangkabau Migrant Merchants. Society, 7(2), 233-250. https:/ / doi.org/10.33019/society.v7i2.110

Hidayati, I. (2019). The Process of Migration and Communication Technology Roles among Labor Migrants in Batam - Indonesia. Society, 7(2), 173-184. https://doi.org/10.33019/ society.v7i2.99

Hidayah A., \& Susilo, W. (2016). Building a Village Caring for Migrant Workers. Migrant Care Jakarta.

Kolopaking, L. M. (2016). Migrasi Gaya Hidup Internasional dan Peminggiran Masyarakat di Desa Tujuan Wisata (Studi di Desa Tugu Selatan Kecamatan Cisarua Kabupaten Bogor 
Jawa Barat). Sodality: Jurnal Sosiologi Pedesaan, 4(1).

https:// doi.org/10.22500/sodality.v4i1.14405

Lailiyah, F. (2018). Problematika Pengasuhan Anak pada Keluarga TKI (Studi di Desa Golokan

Kecamatan Sidayu Kabupaten Gresik) (Thesis). Universitas Airlang. Retrieved from

https://repository.unair.ac.id/72465/

Latifah, S. W., Waluya, A. J., \& Retna, E. R. (2016). Pemberdayaan Mantan TKI melalui

Pengembangan Usaha Berbasis Potensi Lokal. Jurnal Bisnis, Manajemen E Perbankan, 2(1), 67-80.

Laura, N., Sari, R. D., Setiawan, I., \& Herdiyanti, H. (2018). Peran Modal Sosial Masyarakat dalam Pengelolaan Potensi Alam Sebagai Strategi Bertahan Hidup di Dusung Limang, Kecamatan Kelapa, Kabupaten Bangka Barat. Society, 6(2), 74-82. https://doi.org/10.33019/ society.v6i2.68

Lestari, W., Kartono, D. T., Demartoto, A., \& Setiyawan, K. B. (2019). The Empowerment of Households towards Independence through Social Capital in Program Keluarga Harapan (PKH). Society, 7(2), 268-280. https://doi.org/10.33019/society.v7i2.124

Mindarti, L. I., \& Nabil, P. (2019). Pemberdayaan Mantan Pekerja Migran Indonesia Melalui Program Desmigratif (Studi di Desa Arjowilangun Kecamatan Kalipare Kabupaten Malang). Public Administration Journal of Research, 1(4), 421-435. https://doi.org/10.33005/paj.v1i4.26

Muslihudin, M., Wulan, T. R., Sugiarto, T., Wardhianna, S., \& Wijayanti, S. (2019). Integration of Human Resources and the Environment on Productive Migrant Village Programs in Banyumas Indonesia. E3S Web of Conferences, 125, 09014. https:/ / doi.org/10.1051/e3sconf/201912509014

Muslihudin, M., Wulan, T. R., Sugiarto, T., Wardhianna, S., \& Wijayanti, S. (2020). Initial Implementation of Productive Migrant Village (PMV) Programs in Banyumas Central Java Indonesia. SHS Web of Conferences, 86, 01050. https://doi.org/10.1051/shsconf/20208601050

Nuraeni, Y. (2018). Strategi Pengembangan UMKM Berbasis Agroindustri Melalui Program Desa Migran Produktif (Desmigratif) Dalam Rangka Perluasan Kesempatan Kerja. Jurnal Akuntansi Manajerial, 3(1), 42-53.

Prasetyo, D. T. (2017). Pengasuhan Orangtua Terhadap Kondisi Psikologis Anak Yang Ditinggalkan Dalam Keluarga Migran : Sebuah Studi Literatur. JKKP (Jurnal Kesejahteraan Keluarga Dan Pendidikan), 4(2), 58-61. https://doi.org/10.21009/jkkp.042.01

Prihatinah, T., Asyik, N., \& Kartono, K. (2012). Kendala Perlindungan Hukum Terhadap Buruh Migran Di Kabupaten Cilacap. Jurnal Dinamika Hukum, 12(2), 312-320. https:/ / doi.org/10.20884/1.jdh.2012.12.2.55

Ratnaningsih, E. (2017, December 31). Paradigma Baru Perlindungan Pekerja Migran Indonesia. Retrieved from https://business-law.binus.ac.id/2017/12/31/paradigma-baruperlindungan-pekerja-migran-indonesia/

Reni, R., Tarmizi, N., \& Maryadi, M. (2016). Analisis Keputusan Bermigrasi Tenaga Kerja Asal Kabupaten Ogan Ilir Ke Malaysia. I-Economics: A Research Journal on Islamic Economics, 2(2), 74-85.. $\quad$ Retrieved from

http://jurnal.radenfatah.ac.id/index.php/ieconomics/article/view/1025

Rosiyanti, A., \& Gustaman, F. A. (2020). Pemberdayaan Perempuan di Desa Migran Produktif (Desmigratif) Guna Meningkatkan Kemandirian Ekonomi Perempuan Desa Purworejo Kecamatan Ringinarum Kabupaten Kendal. Solidarity: Journal of Education, Society and

Copyright ( $(2021$. Owned by Author(s), published by Society. This is an open-access article under the CC-BY-NC-SA license. https://doi.org/10.33019/society.v9i1.261 
$\begin{array}{llll}\text { Culture, } & 9(1), & \text { 978-989. } & \text { Retrieved }\end{array}$

https://journal.unnes.ac.id/sju/index.php/solidarity/article/view/39910

Rochmadi, I. (2011). Analisis Dampak Perdagangan Bebas dan Global pada Bergesernya Nilai Budaya, Prinsip dan Tujuan Koperasi. Jurnal Ekonomika, 4(2), 45-51.

Republik Indonesia. (2017). Undang-Undang Republik Indonesia Nomor 18 Tahun 2017 Tentang Perlindungan Pekerja Migran Indonesia.

Salim, A. (2013). Management Information in Rural Area: A Case Study of Rancasalak Village in Garut, Indonesia. Procedia Technology, 11, 243-249. https://doi.org/10.1016/j.protcy.2013.12.187

Wulan, T. R., Wijayanti, S., Shodiq, D., \& Ramadhanti, W. (2016). Village as a Basic of Safe Migration: The Enforcement of Head of Village and Local Regulation (Perdes) as a Strategy to prevent Human Trafficking in Banyumas Central Java. Proceedings of the 2016 International Conference on Public Management (ICPM 2016). Published. https://doi.org/10.2991/icpm-16.2016.23

\section{About the Authors}

1. Muslihudin obtained his Doctoral degree in Environmental Science from Universitas Diponegoro, Indonesia, in 2018. The author is an Associate Professor at the Department of Sociology, Faculty of Social and Political Sciences, Universitas Jenderal Soedirman.

E-Mail: muslihudin1963@yahoo.com

2. Tyas Retno Wulan obtained her Doctoral degree from IPB University, Indonesia, in 2010. The author is an Assistant Professor and Head of Department of Sociology, Faculty of Social and Political Sciences, Universitas Jenderal Soedirman.

E-Mail: tyashzul@yahoo.com

3. Tri Sugiarto obtained his Master's degree from Universitas Gadjah Mada, Indonesia, in 1994. The author is an Assistant Professor at the Department of Sociology, Faculty of Social and Political Sciences, Universitas Jenderal Soedirman.

E-Mail: trisugiarto12@gmail.com

4. Sotyania Wardhianna obtained her Master's Degree from Universitas Gadjah Mada, Indonesia, in 1998. The author is an Assistant Professor at the Department of Community Health, Faculty of Health Sciences, Universitas Jenderal Soedirman.

E-Mail: anna.inoel228@gmail.com

5. Sri Wijayanti obtained her Master's Degree from Universitas Gadjah Mada, Indonesia, in 2007. The author is an Assistant Professor at the Department of International Relations, Faculty of Social and Political Sciences, Universitas Jenderal Soedirman.

E-Mail: yantietaslim@yahoo.com

Copyright (C) 2021. Owned by Author(s), published by Society. This is an open-access article under the CC-BY-NC-SA license. 